\title{
Review of CILIP Conference (Connect Debate Innovate) Liverpool 2-3 July 2015
}

Julie Doran

\begin{abstract}
Bringing the information world together is no mean feat, but it is something that the 2015 CILIP conference in Liverpool delivered up for debate through keynote speeches, breakout themes and fringe elements. What the conference essentially asked us to do was "connect with each other", "debate" and "leave inspired" (Parry, 2015, 2). So did this year's conference do the job?
\end{abstract}

\section{Introduction}

The four conference themes this year brought a good many debates, ideas and innovations under the headings of: 'Information Management', 'Information Literacy', 'Demonstrating Value' and 'Digital Futures'.

Along with the keynote addresses, I had chosen to concentrate on the themes of 'Demonstrating Value', focusing on how to evaluate and communicate our value to decision makers, and 'Digital Futures', looking at aspects of research data management and library service innovation, hoping that these would challenge and inspire me. They all did, but here are just a few recollections from CILIP's two day conference.

The CILIP Conference preview issue of CILIP Update $(2015,5)$ introduced a poll to its readers to find out which of the keynote speakers appealed the most. If you did not vote do not worry because they were all good. However, to review all at the conference would prove too much, so I will report on the two keynote speakers that inspired conference attendees each morning. I will follow that with summaries of sessions from my two chosen themes and will end by trying to give you a taste of the additional sites and activities in Liverpool beyond the conference meeting rooms.

\section{Author}

Julie Doran is a Subject Librarian at the University of Gloucestershire.

Email: jdoran@glos.ac.uk

Received 21 July 2015

Accepted 12 October 2015 


\section{Keynote speakers}

Professor R. David Lankes' lively Thursday morning keynote address 'An action plan for world domination through librarianship' set the tone for the rest of the conference. He sought to tear down barriers we build within librarianship between public, private, and academic sectors. He stated, after all, we all do information research, and on that basis we should be able to bridge ideas. This is something that I very much took on board by ensuring that I attended talks by contributors from all sectors.

The positivity he showed toward librarianship was evident in his advice to conquer our demons by tackling the "mousey image" of the librarian and not competing with Google, Amazon and Apple. These companies, he stated, are not information providers, but advertisers and retailers, so librarians still have to educate customers, for example, about how to search Google successfully.

Professor Lankes was most adamant that librarians define the library and not the other way around. We need to recognise the shift in collection management that librarians have gone through, from print to CD Rom into online databases, creating a future profession that could be interacting with its users digitally more than face-to-face within physical buildings, so why should those physical spaces define us? Essentially, he stated, we are the experts in building knowledge; knowledge is learning and librarians should be valued as the educators who facilitate this process.

The next day's first keynote echoed that passion, this time from a great advocate for human rights.

After more than a decade of promoting human rights, as in-house council to Liberty and from 2003 as its director, Shami Chakrabarti held her audience of library, information and knowledge professionals enthralled with her speech on civil liberties. Shami was described by David Aaronovitch from The Times as "probably the most effective public affairs lobbyist of the past 20 years" (Liberty, 2015), and that certainly came across in her speech. She provided many reasons why we should be aware of the government's proposal to scrap the Human Rights Act 1998 in favour of a UK Bill of Rights. You would be forgiven for thinking that such an address would be extremely serious, but there were some very light moments throughout. Shami recollected several stages of her life: how as a child she was taken to the library by her mother, the time she was described as "the most dangerous woman in Britain" by Jon Gaunt (The Sun, 2007, cited by Liberty, 2015), and how, on the publication of her new book, On Liberty (Chakrabarti, 2014), her son gave the following response: "you wrote a short book with large font, mum".

There was no-doubt that the audience felt the debate about the threat to our civil rights required much consideration, regardless of whether they shared the views expressed by the speaker. The discussion carried on into the coffee break, although it seemed a bit frivolous to be rushing for coffee and biscuits having just discussed the horrors which still go on, against the articles of the European Convention on Human Rights (ECHR). 


\section{Digital futures and technology}

In the 'Digital futures' theme, Andrew Cox from the University of Sheffield's Information School suggested that the issues raised by prospects of the digital future are "wicked problems" (Rittel and Webber, 1973). The session became interactive straight away when he asked the audience to discuss complex problems that libraries face; problems that are so complex they may never be solved. He also referred to Grint (2010) in distinguishing wicked problems from tame problems; wicked problems can only be tackled when leadership engages and transforms the group, or followers (Grint, 2010, 18). He named a few reasons for wicked problems such as the difficulty of agreeing a consensus or considerable uncertainty and ambiguity surrounding the tasks involved, and then went on to outline how leadership should operate when faced with these kinds of problems. He stated that it should centre on relationships not structures, reflection not reaction, constructive dissent not destructive consent, collective intelligence not individual genius, and empathy not egotism. Overall, we should see these wicked problems as opportunities to be creative, flexible, collaborative, enterprising and courageous. Technologies were highlighted as a means to connect problems together by linking systems and communities. In fact, he implied it would open up new ways of working. I specifically selected this session on the basis that it would provide some analysis of leadership theory within a library context, and it was dealt with very comprehensively. For those who are interested his paper on this topic will be published in Library Review.

\section{Demonstrating value: - what's your impact?}

Anne Middleton and Elizabeth Oddy delivered an insightful talk on their library initiative 'Popping up a library: a way to impress, inform and influence'. In the autumn 2013, Newcastle University found itself with 1,700 extra students, placing a huge strain on its services, not least the library. It was interesting to hear that the ratio of students per seat in the library was extremely high. The negative effect this could have on student feedback surveys helped the library's strategy to grow and to gain some acceptance. Consultation with the students in February 2014 found that students would like more computer space or individual study spaces, closely followed by group, social and other spaces. All this evidence culminated in a space being found for student learning, a Pop Up Library without any books. The multi-channel marketing campaign led by the library gained them the 2014 CILIP Publicity and Public Relations Group Marketing Excellence (PPRG Gold) Award (CILIP, 2013). Furthermore, the initial project has led to more space being found for growth in study spaces from 600 to 800 spaces from January 2016.

Jo Alcock provided five ways to demonstrate value of library services using usage statistics, and showing how some Universities use these metrics, such as JUSP (Journal Usage Statistics Portal) or IRUS-UK (Institutional Repository Usage Statistics UK), to provide usage statistics in a wider context, to communicate with key stakeholders and to promote advocacy. I will certainly be deploying these metrics in a variety of forms to show our value.

The value of collaboration was evident from Andy Ryan's speech on Cityread, in which 33 London public library services participated in a literature festival. 
Louisa Young's (2011) book, My Dear, I wanted to tell you, was handed out to groups, schools and the public to promote reading. The short video shown (Cityread London, 2014) was professionally shot, and detailed the month-long activities that took place around London, including interactive story telling. It looked absolutely thrilling and I do hope that it will be repeated in other cities. The metrics of footfall, surveys, case studies and examination of benefit to local libraries helped to show its value.

For access to these speaker's presentations and more, see the CILIP conference website (CILIP, 2015).

\section{Beyond the conference}

The venue St George's Hall was impressive, its concert room, used for all keynote presentations, had the most ornate ceiling with chandelier, and the civil court used for digital futures sessions was more austere with its granite columns. The conference location also meant that attendees could easily visit Liverpool's Central Library, the Walker Art Gallery or the World Museum. Those, too, were equally impressive, and Jan Parry (Parry, 2015) was right to point us in the direction of the Picton Reading Room, trumped only by the Aquarium and the Victorian Art Gallery, featuring Rossetti's Dante's Dream.

The drinks reception at the Museum of Liverpool was no less impressive and continued to allow attendees to get to know one another, discuss their situations and the day's conference. If anyone else made it to the Cavern Club on Thursday night they were treated to a Beatles tribute band. Liverpool truly is a delightful city!

\section{Conclusion}

I was delighted to receive the LIRG bursary award to attend this year's conference that respectfully presents all the different areas of the profession together. In my opinion it did that extremely well, and I took back many ideas from public and private sectors, as well as from academic libraries. This was my first CILIP conference, but it certainly will not be my last.

\section{References}

Chakrabarti, S. (2014) On Liberty. Harmondsworth: Allen Lane.

CILIP Update (2015) Pick your favourite Conference keynote. Kent: CILIP.

CILIP (2013) Award winners and past events [online]. URL:

http://www.cilip.org.uk/publicity-and-public-relations-group/cilip-pprg-pastevents-and-award-winners [accessed 11.07.15].

CILIP (2015) Session speakers [online]. URL:

http://cilipconference2015.org.uk/session-speakers-2/ [accessed 11.07.15]. 
Cityread London (2014) Previous Years' Books [online]. URL:

http://www.cityread.london/about/previous-years-books/events-archive-videos/ [accessed 10.07.15].

Grint, K. (2010) Leadership: A very short introduction. Oxford: Oxford University Press.

Liberty (2015) On Liberty: Shami Chakrabati [online]. URL: https://www.libertyhuman-rights.org.uk/who-we-are/structure/liberty-director/liberty-shamichakrabarti [accessed 11.07.15].

Parry, J. (2015) Welcome, CILIP Conference Handbook. London: CILIP Events.

Rittel, H.W.J. and Webber, M.M. (1973) Dilemmas in a general theory of planning. Policy Sciences, 4, 155-169.

\section{The Occasion}

This report was submitted as part of a Library and Information Research Group bursary award to attend the CILIP conference.

\section{Open access and copyright}

Library and Information Research is an open access journal. A freely available copy of this paper may be downloaded from the journal's website: http://www.lirgjournal.org.uk.

Copyright and associated moral rights in works published in Library and Information Research are retained by the author(s) but this paper may be used freely, with proper attribution, in educational and other non-commercial settings. 